\title{
HISTORIA, ARCHEOLOGIA I PALEOBOTANIKA. O DEMASKOWANIU DZIEJÓW W BADAWCZO- -ARTYSTYCZNEJ PRAKTYCE SLAWY HARASYMOWICZ, THIERRY'IEGO OUSSOU ORAZ MICHAELA WANGA
}

\author{
HISTORY, ARCHEOLOGY AND PALEOBOTANY. \\ ON UNMASKING THE PAST IN THE RESEARCH, \\ AND ARTISTIC PRACTICE OF SŁAWA HARASYMOWICZ, \\ THIERRY OUSSOU, AND MICHAEL WANG
}

\author{
Krzysztof Siatka \\ orcid.org/0000-0003-4886-5911 \\ Katedra Nauk o Sztuce, Uniwersytet Pedagogiczny im. Komisji Edukacji Narodowej \\ w Krakowie \\ ul. Mazowiecka 43, 30-019 Kraków \\ krzysztof.siatka@up.krakow.pl
}

\begin{abstract}
The practice of contemporary artists is sometimes similar to the methodology of the researcher of the past. The creators engaged in the discovery of history, generate images of memory using historically or biologically similar methods, among which archival research, archaeological excavations and botanical experiments are a full-fledged artistic method. The reason for the work of Sława Harasymowicz is the nearby history, in which the members of her family and herself participated. Thierry Oussou has recently become famous for the excavation mystic that triggered the diplomatic incident. In his artistic work, Michael Wang raises global themes: climate change and economics. Their projects level the artistic and research work with the process. They reject the dictates of the objectivity, and linearity of the story. The method chosen by them, the questions posed and comments made by commentators are included in the discourse of contemporary humanities, in which the human subject has been included in the system of dependencies between animals, plants, and machines.
\end{abstract}

KEY WORDS: Sława Harasymowicz, Thierry Oussou, Michael Wang, Manifesta, Berlin Biennale

Eksperymenty artystów z formułami twórczości analogicznymi do pracy badacza są dziedzictwem neoawangardy lat 60. i 70. XX wieku. Hans Haacke, na wzór socjologów, udostępniał ankiety w nowojorskim Museum of Modern Art (MoMA Poll, 
1970), a Joseph Beuys już w latach 60. prowadził prelekcje na temat teorii rzeźby społecznej. W XXI wiek wprowadził nas projekt Alba (2000) Eduardo Kaca. Artysta wyhodował fluorescencyjnego królika i otworzył dyskusję o tzw. bioarcie. Doświadczenia sztuki ostatnich lat pokazują jeszcze jedną sferę naukowej eksploracji: artyści chętnie przepracowują odległą sobie przeszłość, a badacze traktują niedawne dzieła jako krytyczną analizę dziejów (Kowalczyk, 2011). Kreowana fikcja artystyczna jest odczytywaniem wydarzeń, eksploracją doświadczenia i świadectwem pamięci, które, dzięki wrażliwości przeciwstawionej obiektywizmowi w podejściu klasycznie naukowym, bardziej niepokoją niż wnioski wysuwane przez tradycyjną historiografię (LaCapra, 2009, s. 171-173).

Zadaniem badaczy pochylających się nad dziejami jest wyjaśnienie przyczyny następstw przy zachowaniu szacunku dla kontekstu dziejowego. Artyści postępują natomiast zgodnie z intuicją, na marginesie naukowej metody, niekonsekwentnie, ale efekty tej pracy mają większą szansę aktualizacji w teraźniejszości. Praktyka artystyczna miewa też aspiracje przekształceń w obrębie systemu tworzenia, kumulowania i udostępniania wiedzy. Alternatywna reprezentacja przeszłości wciąż ma też potencjał przedefiniowania formuł dzieła sztuki, pracy artysty, prezentacji oraz instytucji sztuki i poniekąd instytucji nauki. Bywa eksperymentalna i ryzykowna, przez co niekiedy ożywcza dla dyscyplin.

Proponuję refleksję o wizji przeszłości, która wyłania się w procesie pracy współczesnych artystów. Efekty tego podejścia podlegają sprawdzaniu podczas międzynarodowych przeglądów artystycznych, są prezentowane na wielkich wystawach sztuki współczesnej i konfrontowane z tysiącami widzów. Wizję tę pojmuję jako rozszerzającą dyskurs humanistyki o, jak sądzę, pożądany empatyczny niepokój.

Twórcy w sposób niezwykle efektowny, zajmując się odkrywaniem dziejów, wykorzystują metody zbliżone do nauk historycznych czy biologicznych. Badania archiwalne, wykopaliska archeologiczne czy botaniczne eksperymenty stały się pełnoprawnymi mediami sztuki. Podczas cyklicznych przeglądów sztuki, obok prezentacji dzieł, odbywa się szereg wydarzeń: dyskusji, prelekcji, konferencji. Ich polemiczny, a niekiedy naukowy charakter wzmacniają dyskusję o pożądanej nowej syntezie wiedzy, o teorii i praktyce oraz o nowej humanistyce. To właśnie w ramach wystaw sztuki współczesnej doszły do głosu odświeżające idee alterglobalistycznej historii sztuki, która jest krytyczna wobec centralistycznych praktyk i represji środka względem peryferiów (Piotrowski, 2016, s. 31-56). Podczas Documenta 14 w Kassel i w Atenach w 2017 roku program wydarzeń towarzyszących zatytułowany był Parlament ciał i zwracał uwagę, że najistotniejsze opinie, które mogą sprzeciwić się przemocy polityków i systemów ekonomicznych, należą do „ciał” protestujących na ulicach. Z kolei odsunięcie człowieka z centrum refleksji na rzecz poszukiwania sposobów myślenia, które przekraczają enklawy świata roślin, zwierząt, maszyn i są wyróżnikami filozoficznego posthumanizmu (Braidotti, 2014), były inspiracją dla Manifesta $12 \mathrm{w} 2018$ roku w sycylijskim Palermo. Sygnalizowane tendencje sztuki korelują z bieżącymi i szeroko dyskutowanymi zwrotami w metodologii nauk historycznych, które w dużej części zawierają się w terminie „zwrot ku rzeczom”. Ewa Domańska stwierdziła, że 
w obliczu potęgi postępu technologicznego i biologicznego, który wyraził się w klonowaniu, transplantologii, implantologii oraz nanotechnologii, ,tradycyjne określenie historii jako nauki o ludziach w czasie okazuje się niewystarczające" (Domańska, 2006, s. 104). Humanistyka i sztuka współczesna dostrzegły obiecujące perspektywy badawcze w eksploracji tego, co nieludzkie.

Za przedmiot refleksji przyjąłem działania trójki artystów, młodych i średniego pokolenia, których prace znajdują się w światowym obiegu sztuki. Sława Harasymowicz to artystka polskiego pochodzenia, od kilku dekad mieszkająca w Wielkiej Brytanii, wykształcona w Royal College of Art w Londynie. Przedmiotem jej twórczości są nieodległe dzieje, w których uczestniczyli członkowie jej rodziny oraz pośrednio ona sama. Z kolei urodzony w Beninie Thierry Oussou to artysta wykształcony na Rijksakademie van Beeldende Kunsten w Amsterdamie i na stałe mieszkający w Holandii. Zasłynął niedawno jako mistyfikator wykopalisk, które wywołały niewielki incydent dyplomatyczny. Michael Wang zaś to Amerykanin z Maryland, który odebrał znakomite wykształcenie na uniwersytetach Princeton i Harvarda. W pracy artystycznej zajmują go globalne tematy: zmiany klimatyczne i ekonomia. Bohaterów opowieści łączy zawiła tożsamość, osobiste lub w drugim pokoleniu doświadczenie emigranta, które dla niniejszego zagadnienia ma znaczenie. Wprowadza bowiem perspektywę pożądanej zmienności i oderwania od korzeni. Wszyscy wymienieni ponadto optują za formułą dzieła, która przekracza tradycyjne media na rzecz eksperymentalnych strategii czerpiących ze wszystkich obszarów życia i wiedzy. Harasymowicz prowadzi badania historyczne, Oussou wykopaliska archeologiczne, a Wang zajmuje się paleobotaniką. Ich twórczość nie zamyka się w zrealizowanej formie dzieła, lecz w procesie, który, w myśl tezy Alfreda Gella, lepiej opisywać jako zbiór czynności zmierzających do przemiany rzeczywistości niż symboliczne twierdzenia na temat współczesnego świata (Gell, 1998, s. 6). Ich pracę określają przygotowania, badania, upublicznienie, a zatem i partycypacja w obrębie formatu, która ma aspirację przekraczania standardu salonowego pokazu sztuki i dyskursyfikuje takie pojęcia, jak historia, wartość, miejsce czy tożsamość.

Instalacja 12/6 Sławy Harasymowicz jest wynikiem przemyśleń o miejscu, gdzie artystka spędziła kilka lat w dzieciństwie z rodzicami i młodszą siostrą. Projekt dokumentuje badania nad przemianą struktury mieszkania, a tytuł w rzeczywistości jest adresem lokalu. Opowieść o doświadczeniu wchodzenia w progi kamienicy i mieszkania przy ul. Łobzowskiej w Krakowie jest snuta przy użyciu różnorodnych mediów: rysunku, grafiki, fotografii itd. Kartonowe pudła zostały opakowane w grafiki powielające ornamenty zapamiętane i odnalezione przez artystkę w budynku, wyświetlany film to fragment dokumentu nakręconego przez Telewizję Polską o jej ojcu - znanym poecie Jerzym Harasymowiczu ${ }^{1}$, mural na ścianie galerii to plan lokalu, który w kolejnych latach ulegał rozlicznym dekompozycjom, koperty tworzące formułę kartoteki, wykonane z papieru ściernego, zawierają fotografie dzisiejszych wnętrz kamienicy.

${ }^{1}$ Jerzy Harasymowicz (1933-1999) - poeta o korzeniach polsko-ukraińskich. Jako jeden z pierwszych poruszył tematykę mniejszości łemkowskiej. 
Opowieść ta jest mało komunikatywna, a obecna w niej reprezentacja miejsca mitologizuje go i skutecznie odrealnia. Rozpad struktury wizualnej i narracyjnej koresponduje $\mathrm{z}$ historią mieszkania - miejsca mikrodramatów, rozpadu wartości i generatora doświadczeń traumatycznych, które mają swoje korzenie wiele pokoleń wcześniej i są dziedziczone. Ta szczególna dekompozycja wartości jest związana z koncepcją wystawy The Trouble with Value prezentowanej w krakowskim Bunkrze Sztuki od grudnia 2017 roku, gdzie projekt $12 / 6$ po raz pierwszy ujrzał światło dzienne, a która opowiadała o paradoksach w obrębie wartości symbolicznych (Dittel, Siatka, 2017). Po II wojnie światowej w budynku na Łobzowskiej mieściły się lokale dla przesiedleńców, później mieszkania komunalne, dzisiaj kamienica jest zaniedbana, a w mieszkaniu ma siedzibą escape room o nazwie Lock \& Rool. Zła passa miejsca trwa w najlepsze. Wydaje mi się kluczowe, że tam historia prywatna splotła się z powszechną. To cecha charakterystyczna wielu działań i metody Harasymowicz.

Inna praca Harasymowicz pod tytułem H.N.5 515 (2015) dedykowana jest jednej z największych katastrof morskich II wojny światowej, która miała miejsce 3 maja 1945 roku w pobliżu Lubeki. Trzy niemieckie statki zostały storpedowane przez RAF. Na okrętach znajdowali się polscy i rosyjscy więźniowie ewakuowani z obozu koncentracyjnego, gdzie pracowali przy produkcji detonatorów do rakiet przeciwlotniczych. Jedną z ofiar katastrofy był wuj artystki. Tytuł zaprezentowanego na przełomie 2015 i 2016 roku w galerii Centrala w Birmingham projektu odnosi się do numerów więźniów. Dramatyczna historia, która była przez długie lata ukrywana przed opinią publiczną, została opowiedziana przez autorkę przy użyciu podobnej syntezy mediów jak 12/6 oraz nagrań dźwiękowych (Harasymowicz, 2017).

Opisane instalacje wynikają z rozmyślań o dziejach i umożliwiają wejrzenie w proces badawczy i artystyczny. Eksplorują przy tym metodę porównywania wizerunków miejsc, reprezentacji wydarzeń oraz świadectw powstałych dawniej, które dzisiaj odnajdywane są w archiwach, z tymi, które wciąż są możliwe do stworzenia: grafiki, wideo, nagrania radiowe. Te artefakty w ramach instalacji artystycznej przypominają zbiór bliski archiwum. Entropiczny projekt dostarcza świadectwo odczucia atmosfery miejsca i przestrzeni, ale sądzę, że przede wszystkim daje wgląd w obrazy nabyte i odziedziczone przez autorkę (Belting, 2000, s. 229-230), a których późniejsza utrata i brak wzbudza uporczywy dyskomfort. Artystka identyfikuje się z rzeczywistym, bo archiwalnie potwierdzonym doświadczeniem członków swojej rodziny, których traumę zapośrednicza i w swojej sztuce poddaje procesom afektywnego rozumienia.

Napięcia między pamięcią subiektywną a wiedzą zbiorową ujawniają ciekawą historię kamienicy w centrum Krakowa oraz fatalną pomyłkę lotnictwa brytyjskiego. Miejscem ujawnienia tych opowieści nie jest wydawnictwo naukowe czy uniwersytet, lecz wystawa. Instytucje sztuki przejęły i wzbogaciły dzisiaj w wielu miejscach na świecie kilka funkcji tradycyjnie zarezerwowanych dla jednostek badawczych. Nie chodzi mi w tym miejscu o niewydolność instytucji nauki czy często komentowane ich kryzysy (Readings, 1997), lecz zwracam uwagę na możliwość przyjęcia odmiennych od tradycyjnych optyki i metod charakterystycznych dla innego niż tradycyjne 
pola wytwarzania wiedzy. Ugruntowana realistyczna praktyka czy linearne myślenie prowadzące do prawdy wyrażonej później efektywnym kanałem komunikacji w małym stopniu definiują sztukę współczesną, mimo usilnych starań promocyjnych galerii i muzeów. Uczestnik dyskursu akademickiego jest racjonalnym badaczem historii, a uczestniczka dyskursu sztuki bada dzieje w sposób pragmatyczny, emocjonalny i intuicyjny. Jest to wciąż jednak badanie, które określa formułę wystawy jako metody badawczej, a dzieła sztuki jako głosu we współczesnym dyskursie wiedzy.

Podczas Berlin Biennale w 2018 roku Thierry Oussou zaprezentował projekt zatytułowany Impossible Is Nothing (2016-2018). Artysta zaaranżował i udokumentował rekonstrukcję wykopalisk archeologicznych przeprowadzonych w Alladzie w Beninie. Wykopaliska zostały przygotowane zgodnie z procedurami naukowymi i prawnymi przy udziale studentów archeologii Uniwersytetu Abomey-Calavi. Uczestnicy ku swojmu zdziwieniu odkryli tron należący do króla Béhanzina (1844-1906), który jest w posiadaniu państwa francuskiego od początku lat 90. XIX wieku. Mistyfikacja unaoczniła istnienie zabytku gdzieś poza jego ojczyzną i uwypukliła na nowo fakt zagrabienia. O sprawie zaczęła pisać prasa. Brytyjski The Guardian donosił, że dziekan wydziału archeologii, z którego wywodzili się uczestnicy akcji, zażądał od artysty publicznej deklaracji, że nie będzie wystawiał kopii tronu jako prawdziwego (Berning Sawa, 2018).

Pokazana w Akademie der Künste instalacja składała się z filmu i wykopanych, fałszywych artefaktów. Umieszczoną za ścianą replikę zabytku można było oglądać przez dziurę wielkości monety. Tron przypomina o jak najbardziej autentycznym konflikcie i dyskusji na temat restytucji dóbr kultury. Artystę cytował The Guardian: „Afryka jest opustoszona ze swoich bogactw. Kiedy młodzi studenci chcą pisać o skarbach swojej ojczyzny, muszą udać się do Francji, aby przeprowadzić badania" (Berning Sawa, 2018).

Praca Oussou wskazuje na potrzebę rewizji status quo ustalonego w czasach kolonialnych i jest również następstwem traumy po większej stracie, której symbolem jest tron. Ten proces przepracowania niechcianych wydarzeń odległych w dziejach, w którym najaktywniej uczestniczyli lokalni studenci, nie zbawiał przeszłości ani nie leczył ran. Wręcz przeciwnie, ten artefakt ma moc sprawczą względem wydarzeń i ludzi, nadaje sens życia przedstawicielom wspólnoty, którzy łączą się nad uaktywnionym po latach nieobecności obrazem historii. Bazująca na dezinformacji instalacja artystyczna jest zatem rodzajem performatywnych studiów nad materialnością i tworzy jej imitację, która przekracza historiograficzną analizę obiektu na rzecz poszukiwania sieci połączeń między rzeczami w czasie i ludźmi, który są cząstkami wielkich wspólnot.

10. Berlin Biennale, kuratorowane przez zespół pod kierownictwem Gabi Ngcobo, które w 2018 roku odbyło się pod hasłem We Don't Need Another Hero, dało wiele przykładów obrazu analogicznej traumy. Stawiano bowiem pytania o historię i o podmiot, który sprawuje nad nią władzę. Inspiracją była piosenka Tiny Turner i bohaterka Aunty Entity, w rolę której wcieliła się piosenkarka w filmie Mad Max II. To przywódczyni, która staje się tyranką w procesie budowania lepszego jutra. Najpierw 

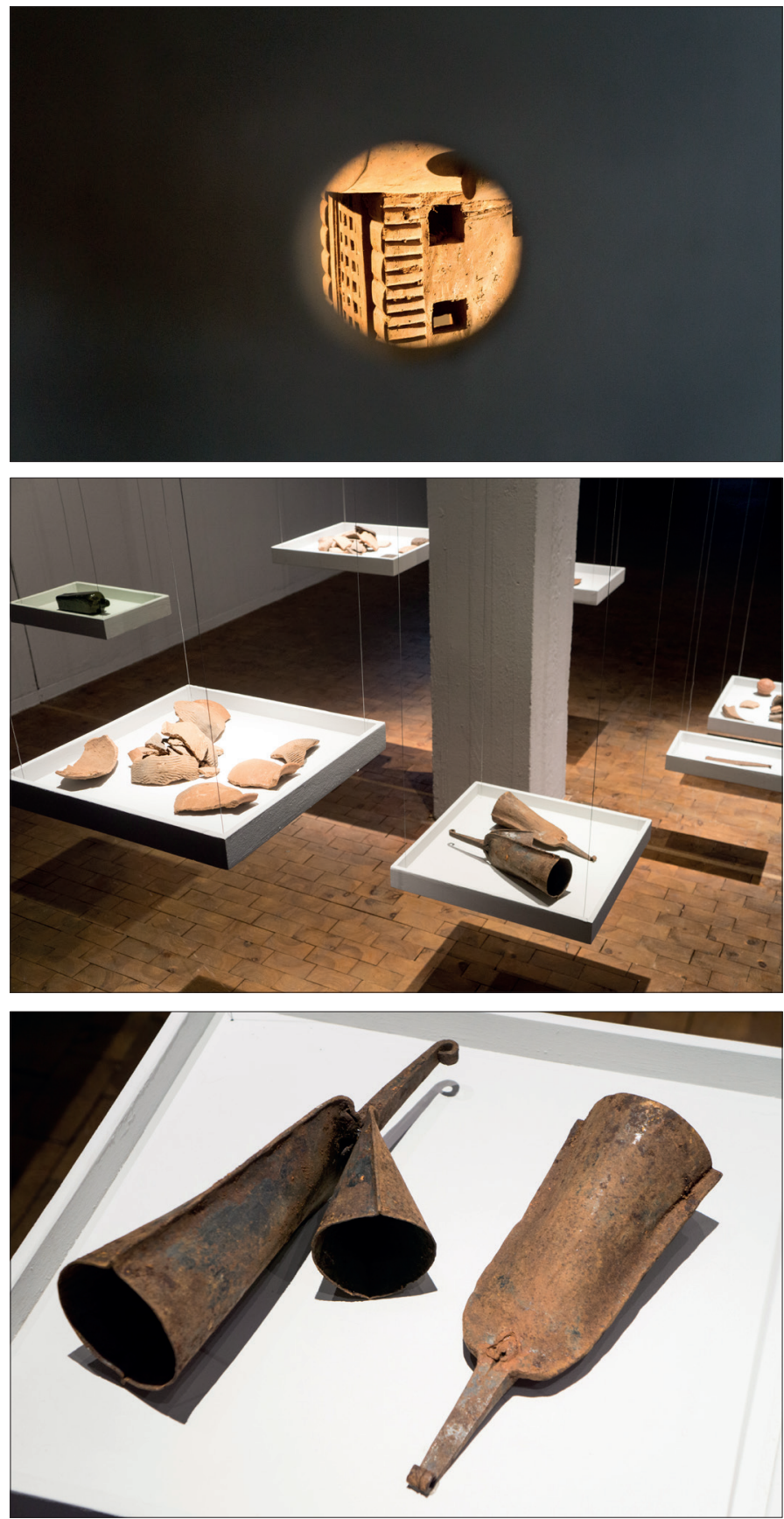

Ryc. 1. Thierry Oussou, Impossible Is Nothing (2016-18), Berlin Biennale 2018, (fot. Krzysztof Siatka)

Fig. 1. Thierry Oussou, Impossible Is Nothing (2016-18), Berlin Biennale 2018 (photo by Krzysztof Siatka) 

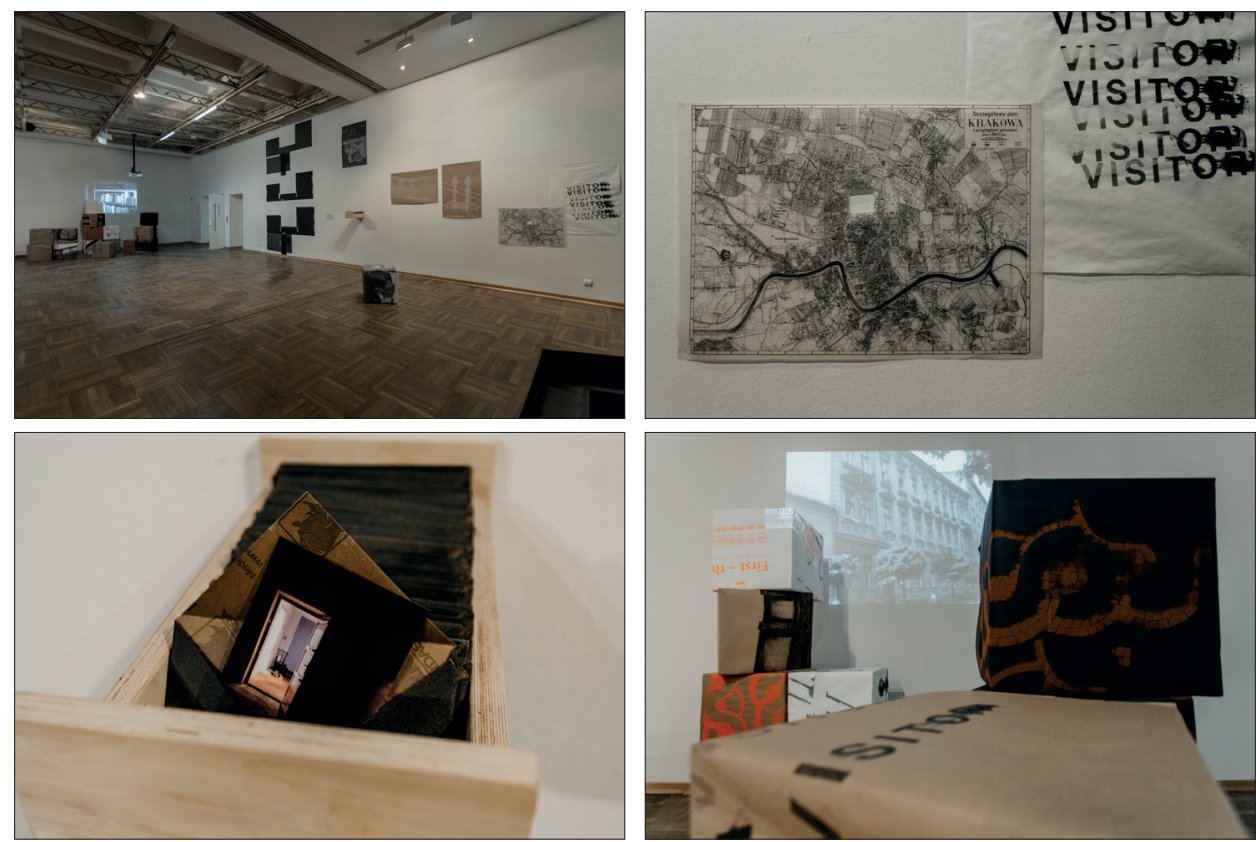

Ryc. 2. Sława Harasymowicz, 12/6, wystawa The Trouble with Value, Galeria Bunkier Sztuki, 2017 (fot. Studio FilmLove)

Fig. 2. Sława Harasymowicz, 12/6, exhibition The Trouble with Value, Bunkier Sztuki Gallery, 2017 (photo by Studio FilmLove)

utożsamiała dobro, a ostatecznie, jak wielu rewolucjonistów, zło w możliwie jaskrawym przykładzie. Obok tego popkulturowego motywem inspirującym wystawę były wydarzenia z 9 kwietnia 2015 roku z kampusu uniwersytetu w Kapsztadzie, kiedy studenci obalili pomnik brytyjskiego kolonizatora Cecila Johna Rhodesa (1853-1902). Obalenie monumentu urosło do rangi symbolu dekolonizacji szkolnictwa wyższego (Ngcobo, 2018, s. 19-23). Niechciany pomnik i pożądany tron to przedmioty, które są w tych konkretnych okolicznościach badania, przepracowywania i udostępniania przyczyną rewizji kolonialnych korzeni i dziedzictwa światowej nauki.

Prace Harasymowicz i Oussou dały prawo głosu przedmiotom stworzonym przez człowieka. Te artefakty można łatwo osadzić w perspektywie nauk humanistycznych i społecznych. Inaczej rzecz ma się z dziełami Michaela Wanga. Interesuje go ujęcie szersze, w którym flora i fauna tworzą wspólny system i wspólną historię. Pojęcie pamięci autor skutecznie rozszerza poza podmiot ludzki. Wykorzystuje ekofakty i czyni je widocznymi w swoich dziełach.

The Drowned World (2018), prezentowany w ramach Manifesta 12 European Nomadic Biennial w Palermo w 2018 roku, składał się z dwóch elementów pochodzenia organicznego skonfrontowanych z następstwami współczesnej industrializacji. Las roślin zbliżonych do tych z okresu karbońskiego rośnie przy pofabrycznych ruinach, 
nieopodal ogrodu botanicznego. Zwiedzający mogą go oglądać z poziomu specjalnie zbudowanej platformy widokowej. Mogą spoglądać za mury ogrodu, wychylając się poza instytucję oświeceniowej wiedzy, stworzonej do uprawy i pielęgnacji leczniczych roślin w 1789 roku. Niezbyt urodziwe miejsce zostało użyte przez artystę w efekcie zastosowania dobrze sprawdzającej się w obrębie pola sztuki metody przejęcia. Był to zabieg, który czytam w kategoriach ironii względem prestiżu ogrodu botanicznego. Zamiast na unikatowych roślinach wzrok widzów ma się koncentrować na chwastach porastających gruzowisko. Artysta jest w tym działaniu radykalny i zdaje się przychylnie spoglądać na miejsca, gdzie przyroda wyzwala się spod ludzkiej dominacji. Monumentalna platforma widokowa to rodzaj trybuny dla widzów, podobnie jak artysta, życzliwych dla naturalnych procesów flory.

Drugi element tego projektu znalazł zastosowanie w ozdobnym basenie fontanny. Pulsującej wewnątrz wodzie zielono-niebieski kolor nadają sinice, pradawne samożywne organizmy, które jako jedne z pierwszych przeprowadziły fotosyntezę przy użyciu chlorofilu. Ponad dwa miliony lat temu ich pojawienie się zapoczątkowało proces biologiczny, przez który światło i powietrze mogą inspirować powstanie materiału organicznego. Ten po raz pierwszy w dziejach planety uwolnił znaczne ilości tlenu do atmosfery. Ponieważ był to gaz toksyczny dla prawie każdej formy ówczesnego życia, tlen atmosferyczny spowodował największe masowe wymieranie w historii Ziemi.

Są to dzieje przedludzkie i przedhistoryczne, kiedy następowały wydarzenia, jakby nie patrzeć, niezbędne dla budowanej później kultury. W tej mozaice alternatywnej wizji dziejów historia sinic, karbońskiego lasu lub fotosyntezy są wydarzeniami istotniejszymi niż niejedna wojna, rewolucja czy stworzone arcydzieło. Ta perspektywa odsuwająca nieco na bok dziedzictwo homo sapiens jest wciąż dla niektórych niepokojąca, a znana nauce od lat 70 . XX wieku, kiedy gen zaczęto opisywać jako cząstkę, której celem jest przetrwanie, a organizm ludzki jedynie jako jej magazyn (Dawkins, 1976). Sugeruję wobec tego spojrzenie na The Drowned World jak na apel o rozszerzenie perspektywy badań przeszłości i jej skutków w teraźniejszości przez porzucenie ludzkiej perspektywy na rzecz poszukiwania podobieństw w różnych formach życia i bycia na Ziemi. Wezwanie to w obliczu kryzysu klimatycznego z każdym kolejnym rokiem wydaje się bardziej niezbędne.

Manifesta 12 były przesiąknięte potrzebą konfrontacji pojęć wytwarzanych przez kulturę i naturę w procesie niepowstrzymanej transformacji. Sycylia, kraina doświadczana przez stulecia zmianami politycznymi, religijnymi, ekonomicznymi, dzisiaj jest przestrzenią utożsamianą ze światowym kryzysem migracji. O innym niż demograficzny aspekcie migracji przypomniał kuratorkom i kuratorom biennale (Bregtje van der Haak, Andrés Jaque, Ippolito Pestellini Laparelli, Mirjam Varadinis) obraz Francesco Lojacono zatytułowany Veduta di Palermo z 1875 roku. Zainspirował twórców wystawy do eksploracji wyobrażenia ogrodu jako miejsca różnorodności, które kształtuje się w wyniku przemieszczania się roślin. Drzewa, krzewy i kwiaty widoczne na obrazie, wizytówki regionu, stanowią dzisiaj o tożsamości Sycylii. Przybywały na wyspę w różnych czasach i podlegały pielęgnacji i rozpowszechnieniu w wyniku 

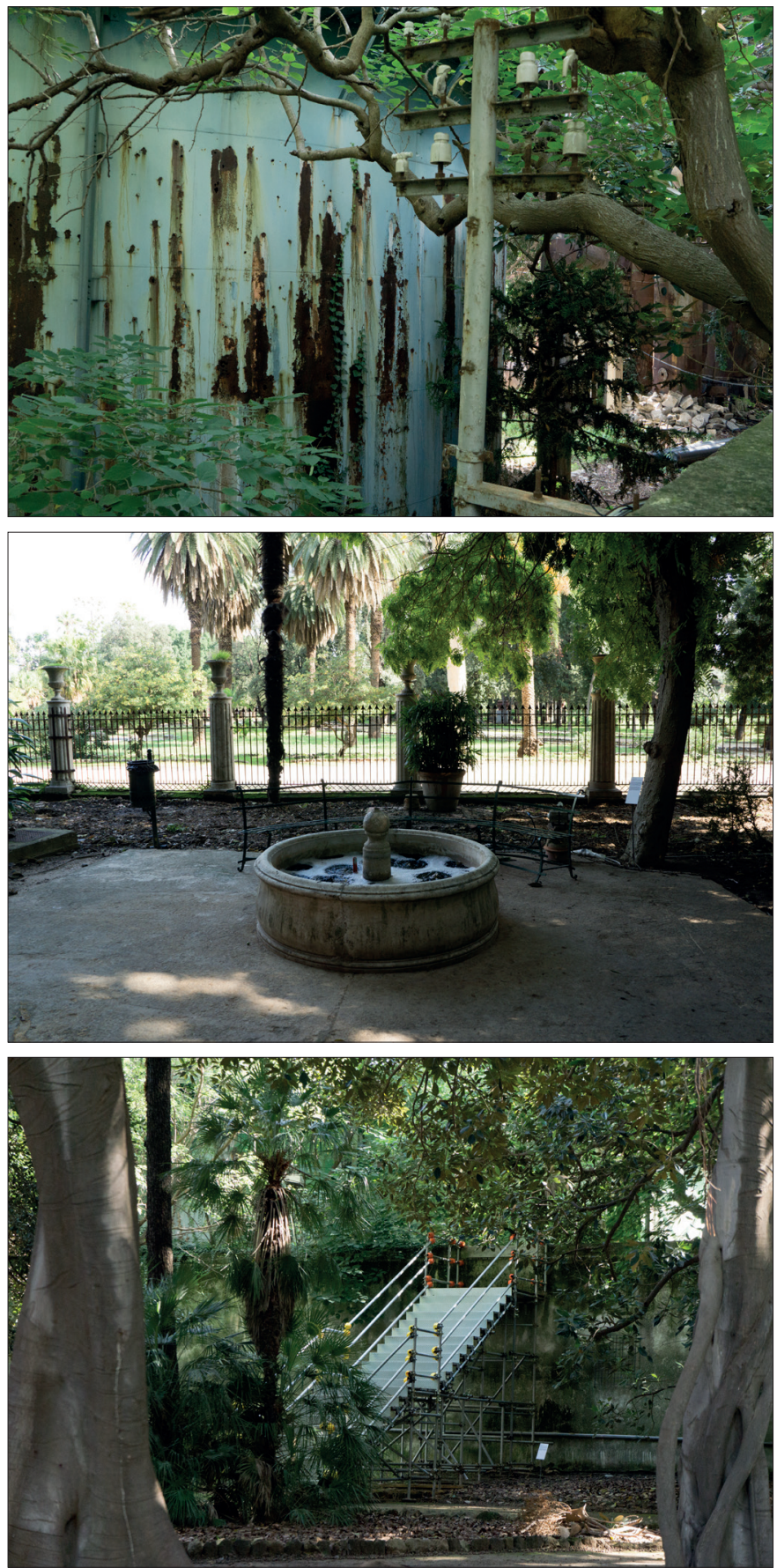

Ryc. 3. Michael Wang, The Drowned World, Manifesta 2018 (fot. Krzysztof Siatka)

Fig. 3. Michael Wang, The Drowned World, Manifesta 2018 (photo by Krzysztof Siatka) 
polityki agrarnej. Pochodzą z całego świata: z bliskiego Wschodu, Australii, Północnej Afryki, obu Ameryk, Azji, Japonii. Wobec tego ogród to miejsce kultywacji koegzystencji różnorodności (Van der Haak, Jaque, Pestellini Laparelli, Varadinis, 2018, s. 19). Rozszerzenie spektrum znaczeń migracji na rośliny, które w równym stopniu co ludzie decydują o tożsamości miejsca, uważam za inspirujące.

Konkludując przedstawione przykłady i stanowisko, uważam, że intermedialna praktyka badawczo-artystyczna ma znaczny potencjał w odsłanianiu i próbie zrozumienia historii, a w szczególności jej mniej spektakularnych momentów, które mogą mieć fundamentalne znaczenie dla losów człowieka i wspólnot. Praktyka ta w moim przekonaniu powinna być postrzegana jako humanistyka w rozszerzonym polu. Rosi Braidotti, filozofka będąca duchową patronką sycylijskiego projektu, przekonywała, że właściwym podmiotem dzisiejszej humanistyki nie jest człowiek. I wyjaśniała, że ,teoria posthumanistyczna wymaga nowej wizji podmiotu, opierającej się na ontologii procesualnej, która rzuca wyzwanie tradycyjnemu zrównaniu podmiotowości z racjonalną świadomością, sprzeciwiając się zredukowaniu zarówno do obiektywności, jak i linearności" (Braidotti, 2018). Nadzieję na rozwój humanistyki wyraziła w postulacie ponownego zjednoczenia zróżnicowanych gałęzi filozofii, nauk ścisłych oraz sztuk w nowym sojuszu. Sądzę, że to przymierze może być budowane w obrębie procesów twórczych. Archiwistyka i translacja obrazów między mediami, mistyfikacja i próby wszczęcia oczyszczającego konfliktu politycznego oraz uwypuklanie procesów biologicznych świadczących o dziejach planety pokazują, że najnowsze pomysły z zakresu filozofii nauki są bliźniaczo podobne do tych w obrębie dyskursu sztuki. Projekty Sławy Harasymowicz, Thierry'iego Oussou oraz Michaela Wanga odrzucają dyktat obiektywizmu i linearności opowieści. Metoda przez nich obrana, stawiane pytania i konstruowane przez komentatorów wnioski zawierają się w czymś znacznie większym niż alternatywne procedury badawcze oraz rozszerzone pole dziedziny. Dotyczy to istotniejszych przesunięć, które dokonują się w procesie konstruowania wiedzy. „Afirmacja a nie nostalgia jest drogą, którą należy podążać” - konkluduje Bradotti. „Nie idealizacja filozoficznego meta-dyskursu, a bardziej pragmatyczne zadanie samoprzemiany w ramach pokornego eksperymentowania" (Braidotti, 2018).

\section{BIBLIOGRAFIA}

Belting, $\mathrm{H}$.

2000 Miejsce obrazów. Artium Quaestiones, 11, 323-338.

Berning Sawa, D.

2018 Watch the throne: why artist Thierry Oussou faked an archaeological dig. The Guardian.

9 lipca Pobrano z: https://www.theguardian.com/artanddesign/2018/jul/09/thierry-oussou-faked-archaeological-dig-african-art-colonial-looting

Braidotti, R.

2018 Ku posthumanistyce. Przekł. Miłosz Markiewicz. Machina myśli. Pobrano z: http://machinamysli.org/2968-2/ 
Braidotti, R.

2014 Po człowieku. Przekł. Joanna Bednarek, Agnieszka Kowalczyk. Warszawa: PWN.

Dawkins, R.

1976 The Selfish Gene. Oxford: University Press.

Dittel, K., Siatka, K. (kuratorzy)

2017 The Trouble with Value. Kraków: Galeria Sztuki Współczesnej Bunkier Sztuki.

Domańska, E.

2006 Historie niekonwencjonalne. Refleksje o przeszłości w nowej humanistyce. Poznań:

Wydawnictwo Poznańskie.

Gell, A.

1998 Art and Agency. An Anthropological Theory. Oxford: Clarendon Press.

Harasymowicz, S. (artystka)

2017 H.N.5 515. Birmingham: Centrala Space.

Van der Haak, B., Jaque, A., Pestellini Laparelli, I., Varadinis, M. (kuratorzy)

2018 Manifesta 12 Palermo The European Nomadic Biennial. Palermo: Editoriale Domus.

Kowalczyk, I.

2011 Podróż do przeszłości. Interpretacje w polskiej sztuce krytycznej. Warszawa: Wydawnictwo SWPS Academica.

LaCapra, D.

2009 Historia $w$ okresie przejściowym. Doświadczenie, tożsamość, teoria krytyczna. Kraków:

Universitas.

Ngcobo, G. (kuratorka)

2018 We don't Need Another Hero. Berlin: Kunst-Werke Berlin e. V.

Piotrowski, P.

2016 Globalne ujęcie sztuki Europy Wschodniej. Poznań: Rebis.

Readings, B.

1997 The University in Ruins. Harvard: University Press.

\section{HISTORY, ARCHEOLOGY AND PALEOBOTANY. ON UNMASKING THE PAST IN THE RESEARCH, AND ARTISTIC PRACTICE OF SŁAWA HARASYMOWICZ, THIERRY OUSSOU, AND MICHAEL WANG}

\section{Su m mary}

The practice of artists is similar to the workshop of the researcher of the past. The artists, while discovering the past, generate the images of memory using the methods related to historical and biological disciplines. The archival queries, archaeological excavations, or botanical experiments are the fully-fledged artistic method. The manifestations of these endeavors may be found in the area of exhibition movement, which in the last years is determined by cyclic parties where together with presentations, there are various events: discussions, lectures, conferences. Its polemic and sometimes academic dimension find itself in the area art and talk about the new synthesis of knowledge-making and new humanities. Among the great exhibitions of the contemporary war, the alter globalism (Piotrowski, 2016, p. 31-56) and post humanistic (Braidotti, 2014) ideas of the history of art are the loudest.

For the point of reflection, I took the activities of three artists, from the young and middle generation, which works circulate in the world art market. Sława Harasymowicz is the artist of Polish 
origin. She has been living in the UK for a few decades, where she studied at the Royal College of Art in London. The reason for the artistic activities is the recent history in which the members of her family took part directly, so as she indirectly. Thierry Oussou, born in Benin, graduated Rijksakademie van beeldende Kunsten in Amsterdam and lives in Holland. Recently, he has become famous for the excavation mystic that triggered the diplomatic incident. Michael Wang is an American born in Maryland who graduated from excellent universities: Princeton and Harvard. In his artistic work, he engages himself in global issues: climate changes and economy. Their creative activity cannot be closed to the form of art, but it is a process. This is determined by preparations, researches, presenting, and participation. They act in the format of a contemporary exhibition that has aspirations to transfer the standards of lounge art presentation.

The installation 12/6 of Sława Harasymowicz is the result of the reflection on the place in which the artist spent a few years in childhood. The project documents research on the transformation of the structure of the home in which she and her younger sister grew up. The story about the experience of entering the townhouse and flat at Łobzowska street in Cracow is told using various media: drawings, graphics, photographs, etc. Cardboard boxes were packed in the graphics multiplying the ornaments remembered and discovered by the artist in the building. The projected film is a fragment of the documented filmed by the Polish TV about her father - a well-known poet Jerzy Harasymowicz ${ }^{2}$, the mural painted on the wall is a plan of a flat which, in the following years, undergone various decompositions, envelopes create a formula of the file, made of sandpaper contains the photographies of contemporary interiors of the townhouse.

The decay of the visual and narrative structure corresponds with the history of the house - the place of micro dramas and breakage of values. In that way, it is linked to the concept of the exhibition The Trouble with Value presented in the Cracow's Art Bunker from December 2017, where the $12 / 6$ was presented. The exhibition aimed at touching the paradoxes of the symbolic values in the area of the contemporary visual arts (Dittel, Siatka, 2017). The entropic project gives us a glimpse of the atmosphere of place and space, but, in my opinion, it mostly presents us the images acquired by the authoress which she inherited after previous generations (Belting, 2000, p. 229-230), and which persistence is the symbol of trauma.

During the Berlin Biennale in 2018, Thierry Oussou presented the project entitled Impossible Is Nothing (2016-18). The artist arranged and documented the reconstruction of the archaeological excavations conducted in Allada in Benin. The research was done according to the archaeological and law procedures with the participation of the archaeology students from the University of Abomey-Calavi. The participants surprisingly discovered the throne, which belonged to the king Béhanzina (1844-1906). The throne is in the deposition of France from the beginning of the 90's of the 19th century. The mystification demonstrated the existence of the artifact somewhere outside of its homeland, and it once again stresses the fact of pillage. Importantly, the case was described by the international press (Berning Sawa, 2018).

The installation presented in the Berlin's Akademie der Kunste consists of the film and excavated, of course, false artifacts. In Berlin, the replica of the artifact placed behind the wall could be seen by the hole in the size of the coin. The throne reminds of the conflict and discussion about the restitution of the cultural goods.

In 2018, the 10th Berlin Biennale, curated by the team lead by Gabi Ngcobo, was entitled We Don't Need Another Hero. The artists asked questions about the history and the entities which rule it. The inspiration for it was a pop song by Tina Turner and a heroine of Mad Max II film, which was played by the singer. Aunty Entity is a ruler that becomes a tyrant while building a better fu-

2 Jerzy Harasymowicz (1933-1999) - a poet with Polish and Ukrainian roots. As one of the first touched the issues of the Lemkos minority. 
ture. Along with the pop-culture motif, another inspiration for the 10th edition of Biennale was the event that happened in the Cape Town's University campus on the 9 April 2015 when the students destroyed the monument presenting Cecila Johna Rhodes - a British colonizer - overthrowing the monument raised to a symbol of decolonization of the higher education (Ngcobo, 2018, p. 19-23). Biennale and political tension raised by the work of Oussou make us to revision the colonial roots of the European academy.

Michael Wang is interested in a broader dimension where flora and fauna create a mutual system and history. The concept of memory effectively spreads the human subject. In his works, the pieces of evidence of history are strictly visible in nature. The Drowned World (2018), presented as a part of Manifesta 12 European Nomadic Biennial in Palermo in 2018, consisted of two elements of organic origin confronted with the consequences of contemporary industrialization. The forest of plants similar to these from the carbon era grows up in the vicinity of the Botanical Garden in Palermo at Sicily. The sightseers may see it from the look-out tower. They can also look beyond the walls of the garden while leaning out the institution of enlightenment knowledge, created to grow and nurture the healing plants in 1798. The artist used the place that is not pretty in the result of using the appropriation method, which is useful in the art. The second element of this project is a little fountain basin. It lights in a blue-green color. The color is made by cyanoses, which, as one of the first, could conduct photosynthesis using chlorofile. This process, for the first time in the world, freed the vast amounts of oxygen to the atmosphere. Thus, it was toxic to almost every form of life, and the atmospheric oxygen caused the biggest mass extinction in the history of our planet. In this mosaic of an alternative vision of the past, the history of cyanoses, the forest from the carbon era, or photosynthesis are more important events than war, revolution, or masterpiece.

Manifesta 12 expressed the need for confronting the terms created by culture and nature in the process of unblocked transformation. Sicily is today the area identified with the world migration crisis. Other than the demographic aspect of migration was introduced to the Biennale curators (Bregtje van der Haak, Andrés Jaque, Ippolito Pestellini Laparelli, Mirjam Varadinis) by the painting of Francesco Lojacono Veduta di Palermo from 1875.

It inspired the exhibition's creators to explore the imagination of the garden as a place of diversity, which is created by the movement and transfers on a global scale. The plans presented in the image are essential for the Sicilian identity. They existed on the island at different times and were nurtured and widespread due to the agrarian policy Van der Haak, Jaque, Pestellini Laparelli, Varadinis, 2018, p. 19).

Rosi Braidotti, a philosopher who is the spiritual patroness of the Sicilian project, argued that a proper subject of humanities is not a human being as such. The hope for the discipline's development is a postulate of a renewed union of diversified branches of philosophy, science, and art. I think that this new union may be built in a range of creative processes. Archive studies and translation of paintings between media, mystification and the trails of initiating a clearing political conflict, as well as foregrounding the biological processes evidencing the history of the planet, show that the new ideas of the philosophy of science find its usage in the discourse of art and functioning of the art institutions.

The projects of Sława Harasymowicz, Michael Wang, Thierry Oussou may be found in the above-described perspective thanks to equating the artistic and researching work with the process, rejecting the dictatorship of objectivism and linearity of the story The method taken by the artists asks questions. Thus the commentators' analysis is part of something bigger than alternative researching procedure and broadened space of the art. 